\title{
OBRAS FÍLMICAS: RECURSO DIDÁTICO DE APRENDIZADO DE GEOGRAFIA
}

\author{
SILVA, Augusto César Pinheiro da - PUC-Rio ${ }^{1}$
}

No livro Aprendendo com filmes: o cinema como recurso didático para o ensino da geografia, os autores ${ }^{2}$ afirmam que é uma obra para quem ama o cinema, mas compreendo que é mais uma obra para quem ama a geografia, e mais do que a própria ciência geográfica, eles amam ensinar a geografia. A produção literária explora a capacidade de o cinema ser um meio didático fundamental de produzir conhecimento, através de obras fílmicas que fazem parte da construção do imaginário espacial da grande maioria dos povos do planeta. Se até Stálin amava o cinema com as suas sessões privadas no Kremlin e o atual ditador norte-coreano Kim Jong-un se refestela com os desenhos e personagens animados produzidos por Walt Disney, que dirá os alunos dos ensinos fundamental e médio da escola básica brasileira.

Nesse sentido, devem ser valorizados os caminhos metodológicos, através dos quais a equipe de pesquisadores do Laboratório de Ensino de Geografia (LEGEO) do CAp-UERJ decidiu trilhar para indicar como os professores devem trabalhar, didaticamente, com alguns filmes (dez obras fílmicas que são recorrentes nas aulas de geografia do ensino médio da rede oficial de educação) para que os alunos entendam as relações sociais, econômicas e culturais da ética ocidental em relação ao poder entre os homens, refletido nos seus espaços de vida (cidades, campos, empresas...) como sujeitos sociais e/ou agentes econômicos e políticos, e como podese viver em um mundo controlado dialogicamente por Estados, empresas e grupos diversos (legais e ilegais) que buscam, através dos seus macro e micropoderes, manterem-se intocados, ao mesmo tempo em que emergem as éticas da humanidade dos outros envolvendo paixões, romances e aventuras. Explicar o mundo com competência é possibilitar ao alunado compreender, através das artes (como o cinema), que a vida deles é reconhecida e identificada por quem recria a realidade através de tramas que se repetem, diariamente, de maneira multilocacional e multiescalar. Nesse contexto, o ensino, a vida cotidiana e as artes se encontram na escola através de um processo educativo que valoriza a pluralidade e o reconhecimento de que o mundo real é mais complexo do que a nossa vã filosofia pode comprovar.

Portanto, o livro é uma obra a ser conferida com bastante atenção, pois nos mostra como agir metodologicamente nas faixas cognitivas desse segmento, além de trazer ricas ilustrações que podem e devem ser usadas pelos professores da área para arejarem os seus discursos, mediarem as suas falam e trazerem mais riqueza visual no cotidiano de suas aulas.

\footnotetext{
${ }^{1}$ Pós-doutorado em Políticas Públicas Educacionais pela Universidad Autónoma de Madrid. Doutor em Geografia pela Universidade Federal do Rio de Janeiro. Professor Adjunto da Universidade do Estado do Rio de Janeiro (UERJ). E-mail: acpinheiro08@gmail.com / augustoc@puc-rio.br.

${ }_{2}^{2}$ Rejane Cristina de Araujo Rodrigues, Fabio Tadeu de Macedo Santana e Leopoldo Carriello Erthal, professores do CAp-UERJ e pesquisadores do Laboratório de Ensino de Geografia (LEGEO).
} 